\title{
Antimicrobial activity of the aqueous extract and fractions from the leaf of the aroeira-do-sertão
}

Atividade antimicrobiana do extrato aquoso e frações da folha da aroeira-do-sertão

\author{
M. J. G. Ferreira ${ }^{1 *}$; F. G. B. Dias ${ }^{1}$; S. M. Santos ${ }^{2}$; N. C. Aquino ${ }^{2}$; E. S. Oliveira ${ }^{1}$; \\ F. E. T. Cunha ${ }^{1}$; L. M. R. Silva ${ }^{1}$; E. A. T. Figueiredo ${ }^{1}$ \\ ${ }^{1}$ Food Engineering Department/Food Microbiology Laboratory, Federal University of Ceara, 60356-000, \\ Fortaleza-CE, Brazil \\ ${ }^{2}$ Organic and Inorganic Chemistry Department/ Phytochemical Analysis of Medicinal Plants Laboratory, Federal \\ University of Ceara, 60020-181, Fortaleza-CE, Brazil \\ *mjaiana@hotmail.com \\ (Recebido em 08 de fevereiro de 2021; aceito em 31 de maio de 2021)
}

\begin{abstract}
The plants popularly used in the treatment of various diseases, such as Myracrodruon urundeuva Allemão, have been investigated about the action on microorganisms, aiming the discovery and use of new natural additives. This research aimed to evaluate the in vitro antimicrobial activity of the aqueous extract of Myracrodruon urundeuva leaves and its fractions on pathogenic bacteria associated with foodborne diseases. The aqueous extract was obtained by decoction of the fresh leaves and fractionated by high-speed countercurrent chromatography. The antimicrobial activity was performed using microdilution in a plate. The aqueous extract of "aroeira-do-sertão" leaves was effective against all tested microorganisms. Antimicrobial activity was verified for Staphylococcus aureus and Listeria monocytogenes $(0.2$ and $0.8 \mathrm{mg} / \mathrm{mL}$, respectively) and for Salmonella Enteritidis, Pseudomonas aeruginosa, and Escherichia coli (6, 10 and 16 $\mathrm{mg} / \mathrm{mL}$ respectively). Twenty-four secondary compounds were isolated, distributed in six fractions. The fractions showed antimicrobial activity on Gram-positive bacteria at low concentrations ( 0.011 to 0.095 $\mathrm{mg} / \mathrm{mL}$ ) and at higher concentrations ( 2.4 to $33 \mathrm{mg} / \mathrm{mL}$ ), two fractions showed activity on Gram-negative bacteria. The union of the compounds in the extract was favorable for antimicrobial activity on all the studied bacteria, demonstrating that the susceptibility of the microorganisms to the extract varied according to the chemical compounds present.

Keywords: bactericidal, isolated compounds, medicinal plant.
\end{abstract}

As plantas popularmente utilizadas no tratamento de várias doenças, como Myracrodruon urundeuva Allemão, têm sido investigadas quanto à ação sobre os microrganismos, visando a descoberta e utilização de novos aditivos naturais. Este trabalho teve como objetivo avaliar a atividade antimicrobiana in vitro do extrato aquoso de folhas de Myracrodruon urundeuva e suas frações sobre bactérias patogênicas associadas a doenças transmitidas por alimentos. O extrato aquoso foi obtido por decocção das folhas frescas e fracionado por cromatografia em contracorrente de alta velocidade. A atividade antimicrobiana foi realizada por meio de microdiluição em placa. O extrato aquoso de folhas de aroeira-do-sertão foi eficaz contra todos os microrganismos testados. A atividade antimicrobiana foi verificada para Staphylococcus aureus e Listeria monocytogenes ( 0,2 e $0,8 \mathrm{mg} / \mathrm{mL}$, respectivamente) e para Salmonella Enteritidis, Pseudomonas aeruginosa e Escherichia coli $(6,10$ e $16 \mathrm{mg} / \mathrm{mL}$, respectivamente). Foram isolados vinte e quatro compostos secundários, distribuídos em seis frações. As frações apresentaram atividade antimicrobiana sobre bactérias Gram-positivas em baixas concentrações $(0,011$ a $0,095 \mathrm{mg} / \mathrm{mL})$ e em concentrações mais altas $(2,4$ a 33 $\mathrm{mg} / \mathrm{mL}$ ), duas frações apresentaram atividade sobre bactérias Gram-negativas. A união dos compostos no extrato foi favorável para atividade antimicrobiana sobre todas as bactérias estudadas, demonstrando que a susceptibilidade dos microrganismos ao extrato variou de acordo com os compostos químicos presentes. Palavras-chave: bactericida, compostos isolados, planta medicinal.

\section{INTRODUCTION}

Plants are used in folk medicine to treat infections, and this has revived the interest of several research groups to study this activity, aiming at the isolation of chemical compounds with antimicrobial activity, or the optimization of the use of these plants [1]. 
Several studies have proven the efficacy of plant extracts on bacterial and fungal pathogens. Researches have shown that microbial sensitivity indicates the effectiveness of extracts used for medicinal purposes and as food additives [2].

Myracrodruon urundeuva Allemão, popularly known as "aroeira-do-sertão", "aroeira-preta", "urundeuvina" or "aroeira-do-campo" is found in the Brazilian caatinga and dry forests of Ceará, being more frequent in the Northeast region [3].

The compounds with pharmacological activity of $M$. urundeuva stem and leaf extracts are tannins, dimeric chalcones, and flavonoids [3]. Scientific research, mostly in vitro work, claims that polyphenols are responsible for the anti-inflammatory, antiproliferative, antioxidant, and antitumor effects [4] and some are considered antimicrobial [5]. Proposed that the tannins obtained from Myracrodruon urundeuva, were able to inhibit the formation of biofilm by damaging the bacterial membrane, thus having bacteriostatic action in some microorganisms [6].

Aiming at the potential present in medicinal plants, and the deficiency of data addressing their research as growth inhibiting agents in food-related microorganisms, this work aimed to evaluate the antimicrobial activity of the aqueous extract and fractions of the leafs of M. urundeuva.

\section{MATERIALS AND METHODS}

\section{Plant material and extraction}

The Myracrodruon urundeuva leaves were collected in august of 2015 at the Urban Agriculture

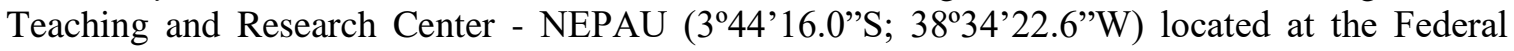
University of Ceará. The aqueous extract was produced at the Laboratory of Phytochemical Analysis of Medicinal Plants - LAFIPLAN of the Department of Organic and Inorganic Chemistry at the Federal University of Ceará with registration number in the SisGen A9B8196.

The plant material was weighed (600g of M. urundeuva fresh leaves) and subjected to manual grinding, being subsequently subjected to hydrodistillation with $2.5 \mathrm{~L}$ of distilled water for 2 hours. After that time, $0.8 \mathrm{~mL}$ of essential oil and $2.3 \mathrm{~L}$ of decoction liquid were obtained. The aqueous solution was dehydrated using a freeze dryer (Christ Model Alpha 1-2 LD plus), obtaining $83.1 \mathrm{~g}$ of the extract and the essential oil was stored [7].

\section{Fractionation of aqueous extract by HSCCC (High Speed-Counter-Current Chromatography)}

The aqueous extract obtained is very polar, so the compound's isolation can be difficult if performed under chromatographic conditions. To avoid irreversible adsorption that can occur with polar adsorbents such as silica gel, the extract was fractionated by high-speed counter-current chromatography (HSCCC - High Speed-Counter-Current Chromatography), (Tauto/Shimadzu LC$10 \mathrm{~A} / \mathrm{Knauer})$ using as a solvent system heptane/AcOEt/MeOH$/ \mathrm{H}_{2} \mathrm{O}(1: 5: 1: 5)$. For the purification of the mixtures, a semi-preparative column with phenyl stationary phase was used in HPLC (Shimadzu Model LC-8A). The identification of these compounds was done using the NMR and MS techniques, as described in our previous work [7]. Weight of fractions: $34-43$ (33 mg); 45-52 (38 mg); 57 (68.3 mg); 71-109 (1.02 g); 122-177 (3.9 mg); 181 (244 mg).

\section{Antimicrobial activity}

The antimicrobial activity analyzes were performed at the Food Microbiology Laboratory LMA of the Federal University of Ceará. The strains of Salmonella Enteritidis IAL-1132, Pseudomonas aeruginosa IAL-1026, Staphylococcus aureus ATCC-27664 and Escherichia coli ATCC-25922 were grown on Soy Agar Tripticase - TSA (Difco, Sparks, USA), while Listeria monocytogenes ATCC-19115 was grown in the same culture medium, but enriched with $0.1 \%$ yeast extract - TSA + YE (Difco, Detroit, USA). The strains were incubated at $35^{\circ} \mathrm{C} / 24$ hours in BOD (Biochemical Oxygen Demand, Quimis / Model Q316-M26) and after that period, colonies isolated 
from each microorganism were transferred to $5 \mathrm{~mL}$ of the soybean tripe enrichment broth - TSB (Difco, Sparks, USA). Then, they were incubated at $35^{\circ} \mathrm{C} / 24$ hours in the BOD to obtain a final bacterial concentration of approximately $10^{8} \mathrm{CFU} / \mathrm{mL}$ for each microorganism. From this concentration, serial dilutions $\left(10^{-1}\right.$ to $\left.10^{-7}\right)$ were performed in order to obtain a bacterial suspension of $10^{5} \mathrm{CFU} / \mathrm{mL}$.

The minimum inhibitory concentration (MIC) of the aqueous extract and fractions was determined on the growth of pathogenic bacteria by the microdilution method in plates (96 wells, $300 \mu \mathrm{L}$ capacity / well; MicrotestTM, Becton Dickinson and Co.) [8].

All analyses were performed using a laminar flow hood (Pachane/model 410) with three replications. The total volume of $200 \mu \mathrm{L}$ was distributed among equal parts of the bacterial suspension $\left(10^{5} \mathrm{CFU} / \mathrm{mL}\right)$ and antimicrobial solution. Concentrations 0.03 to $16 \mathrm{mg} / \mathrm{mL}$ were used for the aqueous extract and 0.004 to $50 \mathrm{mg} / \mathrm{mL}$ for the fractions, prepared with sterile distilled water. The following control were used: inoculum, culture medium and sterile distilled water (positive control) to evaluate the viability of the tested microorganism, as well as wells containing culture medium and antimicrobial solutions in the tested concentrations (control of solutions) to verify the safety of them. At the end of the distributions, the initial optical density reading D. ${ }_{630 \mathrm{~nm}}$ $(\mathrm{T}=0)$ was performed using an absorbance reader on Elx 808 microplates (Instruments BioTek, Inc. Winooski, VT, USA). Then, the plates were incubated at $35 \pm 1{ }^{\circ} \mathrm{C}$ for 24 hours. After this period, a new reading D. $\mathrm{O}_{630 \mathrm{~nm}}(\mathrm{~T}=24)$ was performed. Concentrations that showed results whose variation $(\Delta)$ of the D. $\mathrm{O}_{630 \mathrm{~nm}}$ readings were $\leq 0.05$ [9] were classified as inhibitory.

A $100 \mu \mathrm{L}$ aliquot of each concentration of the tested antimicrobial solutions was spread on the surface of the plates (Spread plate) containing the TSA medium. Then, the plates were incubated at $35{ }^{\circ} \mathrm{C}$ for 24 hours in the BOD. The concentration of the tested antimicrobial solution that provided a reduction of three logarithmic cycles $(3.0 \log 10 \mathrm{CFU} / \mathrm{mL})$ of viable cells from the concentration of the initial inoculum $\left(10^{5} \mathrm{CFU} / \mathrm{mL}\right)$ was classified as minimum bactericidal concentration $(\mathrm{MBC})[8,9]$.

\section{RESULTS AND DISCUSSION}

\section{Antimicrobial activity of M. urundeuva fractions}

Preliminary studies of the extract indicate characteristic compounds of gallotannins and other phenolic derivatives, which is in agreement with studies carried out with the ethanolic extract of mastic leaves [10]. The phenyl stationary phase column proved to be efficient in the purification of mixtures containing compounds of high polarity.

Aquino et al. (2019) [7] related the chemical composition of the six fractions and the identification of twenty-four compounds in aqueous extract (Table 1). The composition of the fractions were: Fraction 34-43 (quinic acid; gentisic acid; quercetin 3-O-(2"-galloyl)- $\beta$-Darabinofuranoside; quercetin 3-O-(2"-galloyl)- $\alpha$-L-rhamnopyranoside and quercetin 3-O-(3"galloyl)- $\alpha$-L-rhamnopyranoside), Fraction 45-52 ( $m$-digallic acid and $p$-digallic acid), Fraction 57 (gallic acid), Fraction 71-109 (methyl gallate; 2,3,4,6-Tetra- $O$-galloyl- $\beta$-D-glucopyranose; 1,2,3,4,6-penta- $O$-galloyl- $\beta$-D-glucopyranose; methyl $m$-digallate; methyl $p$-digallate and 3-O- $(m$ digalloyl)-1,2,4,6-tetra- $O$-galloyl- $\beta$-D-glucopyranose), Fraction 122-177 (1- $O$-galloyl-6- $O$ luteoyl- $\alpha$-glucose; corchoionosídeo C; kaempferol 3-O-rutinoside; homovitexin; quercetin 3-O- $\beta$ D-glucoside; 1,2,3,4,6-penta- $O$-galloyl- $\beta$-D-glucopyranose; rhoifolin and 3 - $O$-( $m$-digalloyl)1,2,4,6-tetra- $O$-galloyl- $\beta$-D-glucopyranose) and Fraction 181 ( $N$-methyl-trans-4-hydroxy-Lproline; quinic acid).

The chemical compounds found by Pinho et al. (2012) [11] are in agreement with those found in the present study. The metabolites isolated and identified in the extract of the leaves of $M$. urundeuva (Table 1). 
Table 1. Class of metabolites of Myracrodruon urundeuva leaf extract.

\begin{tabular}{|c|c|c|}
\hline Metabolites & Compound & References \\
\hline Non-protein aminoacid & $N$-Methyl-trans-4- hydroxy-L-proline & [12] \\
\hline Carboxilic acid & Quinic acid & [13] \\
\hline $\begin{array}{l}\text { Polyphenol carboxylic } \\
\text { acid derivatives }\end{array}$ & $\begin{array}{l}\text { Gallic acid/ Pyrogallol/ Gentisic acid/ } m \text { - } \\
\text { Digallic acid/ } p \text {-Digallic acid/ Methyl gallate/ } \\
\text { Methyl } m \text {-digallate/ Methyl } p \text {-digallate }\end{array}$ & {$[14,15]$} \\
\hline Flavonoids & Quercetin & - \\
\hline Glycosylated flavonoids & $\begin{array}{l}\text { Kaempferol 3- } O \text {-Rutinoside/ Homovitexin/ } \\
\text { Quercetin 3- } O-\beta \text {-D-glucoside/ Rhoifolin/ } \\
\text { Quercetin 3- } O \text {-(2''-galloyl)- } \beta \text {-D- } \\
\text { arabinofuranoside/ Quercetin 3-O-(2',- } \\
\text { galloyl)- } \alpha \text {-L-rhamnopyranoside/ Quercetin 3- } \\
O-(3 \text { '’-galloyl)- } \alpha \text {-L-rhamnopyranoside }\end{array}$ & {$[16,17]$} \\
\hline Gallotannins & $\begin{array}{c}\text { 1- } O \text {-Galloyl-6- } O \text {-luteoyl- } \alpha \text {-glucose/ } 2,3,4,6- \\
\text { Tetra- } O \text {-galloyl- } \beta \text {-D-glucopyranose/ } 1,2,3,4,6- \\
\text { Penta- } O \text {-galloyl- } \beta \text {-D-glucopyranose/ } 3-O \text { - }(m- \\
\text { digalloyl)-1,2,4,6-Tetra- } O \text {-galloyl- } \beta \text {-D- } \\
\text { glucopyranose } \\
\end{array}$ & {$[18,19]$} \\
\hline Megastigmane & Corchoionoside C/ 9-epi-Blumenol & {$[20,21]$} \\
\hline
\end{tabular}

Source: Aquino et al. (2019) [7].

Other studies describe that flavonoids (flavones, flavonols and flavanonols) [22] and saponins [23] have important antimicrobial activity. The phenolic compounds are present in the fractions (Table 2) obtained, being related to the cultivation conditions of the plant, being synthesized as a response to stress, attack by microorganisms or strong UV radiation [24]. The inhibitory effect of these can be explained by their interaction with bacterial membrane proteins through hydrogen bonding, which can result in changes in their permeability, causing cell destruction or coagulation of their content [24].

Table 2. Antimicrobial activity of fractions of Myracrodruon urundeuva leaf.

\begin{tabular}{ccccccccccc}
\hline \multirow{2}{*}{ Fractions } & \multicolumn{10}{c}{ Microorganisms } \\
\cline { 2 - 12 } & \multicolumn{1}{c}{ L. monocytogenes } & \multicolumn{1}{c}{ S. aureus } & \multicolumn{2}{c}{ S. Enteritidis } & \multicolumn{2}{c}{ E. coli } & \multicolumn{2}{c}{ P. aeruginosa } \\
\cline { 2 - 6 } & MIC & MBC & MIC & MBC & MIC & MBC & MIC & MBC & MIC & MBC \\
\hline $\mathbf{3 4 - 4 3}$ & - & - & 0.090 & 0.095 & - & - & - & - & - & - \\
$\mathbf{4 5 - 5 2}$ & - & - & - & - & - & - & - & - & - & - \\
$\mathbf{5 7}$ & 0.040 & 0.070 & 0.008 & 0.011 & - & - & - & - & - & - \\
$\mathbf{7 1 - 1 0 9}$ & 0.070 & - & 0.070 & 0.085 & 2.4 & 2.4 & 33 & 33 & 33 & 33 \\
$\mathbf{1 2 2 - 1 7 7}$ & - & - & - & - & - & - & - & - & - & - \\
$\mathbf{1 8 1}$ & 35 & - & 30 & - & - & - & - & - & 45 & - \\
\hline
\end{tabular}

$\mathrm{MIC}=$ Minimum Inhibitory Concentration $(\mathrm{mg} / \mathrm{mL}) . \mathrm{MBC}=$ Minimum Bactericidal Concentration $(\mathrm{mg} / \mathrm{mL})$.

Gallic acid can be considered a potential antibacterial agent and was found in two fractions in association with tannins, including in the fraction 71-109. The results showed activity on all bacteria studied and in small concentrations for Gram-positive bacteria. According to Borges et al. (2013) [25], gallic acid produces irreversible changes in the properties of the bacterial cell membrane, such as a change in hydrophobicity, a decrease in the negative surface charge and the occurrence of rupture or formation of pores in the cell membranes with the consequent leakage of essential intracellular constituents, such as potassium. In this research, the authors showed antimicrobial activity on E. coli, $P$. aeruginosa, $S$. aureus and L. monocytogenes using gallic acid corroborating the results of this research. 
The mechanism of action of tannins can be explained by its ability to precipitate proteins from mucosal and tissue surface cells, forming a protective layer, inhibiting enzymes, causing a rupture of the plasma membrane and deprivation of the microbial substrate by forming a tannin complex protein and/or polysaccharide, thus preventing the development of microorganisms [26].

Observed that fractions of tannins and other phenols extracted from Rubus ulmifolius showed high antimicrobial activity [27]. The tannins showed activity on P. aeruginosa and S. aureus, with varying concentrations due to the plant material being dry or fresh and the method of diffusion in agar and disc [26]. Because they are fractions, they were obtained in small quantities, mainly the fraction 122-177 and 45-52, a fact that made the tests difficult and it was not possible to find antibacterial activity.

In the fractions 34-43 and 57, a common class of metabolites was found derivatives of polyphenol carboxylic acid and both fractions showed only activity for Gram-positive bacteria at low concentrations. In general, Gram-negative bacteria are more resistant to antimicrobials of plant origin due to their outer lipopolysaccharide membrane, which restricts the diffusion of hydrophobic compounds, while being permeable to nutrients [28].

According Rodrigues et al. (2014) [26], in their research demonstrated that the isolation of tannins improved antimicrobial activity in relation to the crude extract of Psidium guineense. These data corroborated with the isolated fractions in the present work. According to the classification proposed by Aligianis et al. (2001) [29], MIC values $\leq 0.5 \mathrm{mg} / \mathrm{ml}$ are considered to be strongly inhibitory in the case of plant matter.

The presence of proline derivative might be linked to the water stress suffered by the plant, corroborating studies by Gimenez et al. (2013) [30], who showed an accumulation of proline in response to the water deficit in sugarcane. In the fraction 181, containing the proline derivative $(\mathrm{N}$ Methyl-trans-4-hydroxy-L-proline), it was evidenced inhibitory activity on L. monocytogenes, $S$. aureus, and $P$. aeruginosa. The proline derivative was also found in Syderoxylon obtusifolium, another Caatinga plant as reported [31].

\section{Antimicrobial activity of $M$. urundeuva leaf aqueous extract}

The aqueous extract of the aroeira leaf was effective against all the microorganisms tested, varying in concentrations from 0.2 to $16 \mathrm{mg} / \mathrm{mL}$ (Table 3).

Table 3. Antimicrobial activity of the aqueous extract of the leaf of Myracrodruon urundeuva.

\begin{tabular}{|c|c|c|}
\hline \multirow[b]{2}{*}{ Microorganism } & \multicolumn{2}{|c|}{ Aqueous extract of $M$. urundeuva } \\
\hline & MIC (mg/mL) & $\mathrm{MBC}(\mathrm{mg} / \mathrm{mL})$ \\
\hline L. monocytogenes & 0.04 & 0.8 \\
\hline S. aureus & 0.1 & 0.2 \\
\hline S. Enteritidis & 5 & 6 \\
\hline E. coli & 6 & 16 \\
\hline P. aeruginosa & 3 & 10 \\
\hline
\end{tabular}

For Gram-negative bacteria ( $S$. Enteretidis, E. coli and P. aeruginosa) a higher concentration of the extract was necessary to obtain a bactericidal effect due to its cell structure and composition (Table 3). Attributed the greater resistance of Gram-negative bacteria to the cellular structure and composition of these microorganisms, since the double membrane forms a complex envelope that restricts the penetration of most molecules, being responsible for the resistance of these microorganisms to plant extracts [24].

In study with hydroalcoholic extract of aroeira-do-sertão leaves, showed through phytochemical screening, that the leaf contains secondary metabolites with antimicrobial activity, such as flavonoids (flavanones and flavanonols), saponins, tannins and cachectic tannins [11], in agreement with those found in the present study. These metabolites were responsible for the plant's antimicrobial activity, confirming the growth inhibition of $S$. aureus in concentrations ranging from 
$200 \mathrm{mg} / \mathrm{mL}$ to $500 \mathrm{mg} / \mathrm{mL}$, with bacteriostatic activity of $200 \mathrm{mg} / \mathrm{mL}$, but there was no inhibition of E. coli.

The concentrations found in the present study were much lower, showing the importance of the solvent in the preparation of the extracts. Since the aqueous extract showed better antibacterial activity for Gram-positive and Gram-negative when compared with the data by Pinho et al. (2012) [11] who used hydroalcoholic extract.

Found greater amounts of tannins in the leaves than in the bark of M. urundeuva [32]. The antimicrobial action of tannins is well known [33], and it has already been found that aqueous and acetone extracts lose their activity against Gram-positive bacteria when their tannin content is eliminated [34]. Proposed that the tannins obtained from Caatinga plants, including $M$. urundeuva, were able to inhibit biofilm formation by damaging the bacterial membrane, thus exhibiting bacteriostatic properties [6].

The fractions showed an important antimicrobial activity on Gram-positive, although high concentrations were required to show antimicrobial activity on Gram-negatives. The combination of these fractions had a synergistic effect potentiating the analyzed extract, showing it was possible, in lower concentrations, to obtain bactericidal activity on L. monocytogenes, S. aureus, $S$. Enteritidis, E. coli, and P. aeruginosa.

\section{CONCLUSION}

In conclusion, the leaf aqueous extract of aroeira-do-sertão showed to be a promising antimicrobial agent due to its action on L. monocytogenes, S. aureus, E. coli, S. Enteritidis, and $P$. aeruginosa. In virtue to the composition of the fractions obtained from the extract, an important antimicrobial activity was observed in Gram-positives bacteria.

\section{ACKNOWLEDGEMENTS}

Sincerely thanks to Cearense Foundation to Support Scientific and Technological Development (Fundação Cearense de Apoio ao Desenvolvimento Científico e Tecnológico - FUNCAP), National Council for Scientific and Technological Development (Conselho Nacional de Desenvolvimento Científico e Tecnológico - CNPq) and Laboratory for Editing, Translating and Reviewing Academic Texts (Laboratório de Edição, Tradução e Revisão de Textos Acadêmicos LETRARE/UFC).

\section{REFERENCES}

1. Silva MSP, Brandão DO, Chaves TP, Filho ALNF, Costa EMMB, Santos VL, Medeiros ACD. Study bioprospecting of medicinal plant extracts of the semiarid Northeast: Contribution to the control of oral microrganisms. Evid-Based Compl Alt. 2012;2012:1-6, doi: 10.1155/2012/681207

2. Fawad AA, Myaddad-ur-Rehamn NK, Khan SA. Antimicrobial activity of Eucalyptus tereticornis and comparison with daily life antibiotics. Int J Pharm Sci Rev Res. 2012;12(1): 21-29.

3. Galvão WRA, Filho RB, Canuto KM, Ribeiro PRV, Campos AR, Moreira ACOM, Silva SO, Filho FAM, Santos SAAR, Junior JMAM, Gonçalves NGG, Fonseca SGC, Bandeira MAM. Gastroprotective and anti-inflammatory activities integrated to chemical composition of Myracrodruon urundeuva Allemão a conservationist proposal for the species. J Ethnopharmacol. 2018;222:177-89, doi: 10.1016/j.jep.2018.04.024

4. Romano B, Pagano E, Montanaro V, Fortunato AL, Milic N, Borrelli F. Novel Insights into the pharmacology of flavonoids. Phytother Res. 2013;27(11):1588-96, doi: 10.1002/ptr.5023

5. Figueredo FG, Lucena BFF, Tintino SR, Matias EFF, Leite NF, Andrade JC, Nogueira LFB, Morais EC, Costa JGM, Coutinho HDM, Rodrigues FFG. Chemical composition and evaluation of modulatory of the antibiotic activity from extract and essential oil of Myracrodruon urundeuva. Pharm Biol. 2014;52(5):560-65, doi: 10.3109/13880209.2013.853810

6. Trentin DS, Silva DB, Amaral MW, Zimmer KR, Silva MV, Lopes NP, Giordani RB, Macedo AJ. Tannins possessing bacteriostatic effect impair Pseudomonas aeruginosa adhesion and biofilm formation. Plos One. 2013;8(6):e66257, doi: 10.1371/journal.pone.0066257 
7. Aquino NC, Queiroz EF, Marcourt L, Freitas LBN, Araújo EVO, Leal LKAM, Bezerra AME, Boccard J, Wolfender JL, Silveira ER. Chemical composition and anti-inflammatory activity of the decoction from leaves of a cultivated specimen of Myracrodruon urundeuva. J Braz Chem Soc. 2019;30(8):1616-23, doi: 10.21577/0103-5053.20190060

8. Branen JK, Davidson PM. Enhancement of nisin, lysozyme, and monolaurin antimicrobial activities by ethylenediaminetetraacetic acid and lactoferrin. Int J Food Microbiol. 2004;90:63-74, doi: 10.1016/S0168-1605(03)00172-7

9. Brandt AL, Castillo A, Harris KB, Keeton JT, Hardin MD, Taylor TM. Inhibition of Listeria monocytogenes by food antimicrobials applied singly and in combination. J Food Sci. 2010;75(9):M55763, doi: $10.1111 / \mathrm{j} .1750-3841.2010 .01843 . \mathrm{x}$

10. Silva VC, Napolitano A, Eletto D, Rodrigues CM, Pizza C, Vilegas W. Characterization of gallotannins from Astronium species by flow injection analysis-electrospray ionization-ion trap-tandem mass spectrometry and matrix-assisted laser desorption/ionization time-of- flight mass spectrometry. Eur J Mass Spectrom. 2011;17(4):365-75, doi: 10.1255/ejms.1141

11. Pinho L, Souza PNS, Sobrinho EM, Almeida AC, Martins ER. Atividade antimicrobiana de extratos hidroalcóolicos das folhas de alecrim-pimenta, aroeira, barbatimão, erva baleeira e do farelo da casca de pequi. Cienc Rural. 2012;42(2):326-31.

12. Winkler T. Spectral assignments and reference data: Comments on 'Piperidone derivative from Dalbergia sympathetica'. Magn Reson Chem. 2006;44:571-72, doi: 10.1002/mrc.1783

13. Kelley CJ, Harruff RC, Carmack M. The polyphenolic acids of Lithospermum ruderale. II. Carbon-13 nuclear magnetic resonance of lithospermic and rosmarinic acids. J Org Chem. 1976;41(3):449-55, doi: 10.1021/jo00865a007

14. Moura ACS, Vilegas W, Santos LC. Identificação de alguns constituintes químicos de Indigofera hirsuta Linn. (Fabaceae) por CLAE-IES-EM (TOF) e avaliação da atividade antirradicalar. Quim Nova. 2011;34(7):1136-40, doi: 10.1590/S0100-40422011000700006

15. Kulkarni A, Suzuki S, Etoh H. Antioxidant compounds from Eucalyptus grandis biomass by subcritical liquid water extraction. J Wood Sci. 2008;54(2): 153-57, doi: 10.1007/s10086-007-0916-6

16. Moon JH, Tsushida T, Nakahara K, Terao J. Identification of quercetin 3-O-b-D-glucuronide as an antioxidative metabolite in rat plasma after oral administration of quercetin. Free Radical Bio Med. 2001;30(11):1274-85, doi: 10.1016/s0891-5849(01)00522-6

17. Sousa EA, Silva AACA, Cavalheiro AJ, Lago JHG, Chaves MH. A New Flavonoid Derivative from Leaves of Oxandra sessiliflora R. E. Fries. J Braz Chem Soc. 2014;25(4):704-8, doi: 10.5935/01035053.20140023

18. Wang Y, Yang J, Wang A, Ma J, Tan J, Ji T, Su Y. Hydrolyzable tannins from Balanophora polyandra. Acta Pharm Sin B. 2013;3(1):46-50, doi: 10.1016/j.apsb.2012.12.003

19. Santos RT, Hiramoto LL, Lago JHG, Sartorelli P, Tempone AG, Pinto EG, Lorenzi H. Anti-trypanosomal activity of 1,2,3,4,6-penta-o-galloyl-B-d-glucose isolated from Plectranthuns barbatus Andrews (Lamiaceae). Quim Nova. 2012;35(11):2229-32, doi: 10.1590/S0100-40422012001100025

20. Yoshikawa M, Shimada H, Saka M, Yoshizumi S, Yamahara J, Matsuda H. Medicinal Foodstuffs. V. Moroheiya. (1): Absolute Stereostructures of Corchoionosides A, B, and C, Histamine Release Inhibitors from the Leaves of Vietnamese Coorchorus olitorius L. (Tiliaceae). Chem Pharm Bull. 1997;45(3):4649, doi: $10.1248 / \mathrm{cpb} .45 .464$.

21. Matsunami K, Hideaki O, Takeda Y. Structural Revisions of Blumenol C Glucoside and Byzantionoside B. Chem Pharm Bull. 2010;58(3):438-41, doi: 10.1248/cpb.58.438

22. Cushnie TP, Lamb AJ. Antimicrobial activity of flavonoids. Int J Antimicrob Agents. 2005;26(5):34356, doi: 10.1016/j.ijantimicag.2005.09.002

23. Verdi LG, Brighente IMC, Pizzolatti MG. Gênero Baccharis (Asteraceae): aspectos químicos, econômicos e biológicos. Quim Nova. 2005;28(1):85-94, doi: 10.1590/S0100-40422005000100017

24. Oliveira DA, Angonese M, Gomes C, Ferreira SRS. Valorization of passion fruit (Passiflora edulis sp.) by-products: Sustainable recovery and biological activities. J Supercrit Fluids. 2016;111:55-62, doi: 10.1016/j.supflu.2016.01.010

25. Borges A, Ferreira C, Saavedra MJ, Simões M. Antibacterial activity and mode of action of ferulic and gallic acids against pathogenic bacteria. Microb Drug Resist. 2013;19(4):256-65, doi: $10.1089 / \mathrm{mdr} .2012 .0244$

26. Rodrigues CG, Ferreira PRB, Oliveira CSM, Reis Júnior R, Valério HM, Bramdi IV, Oliveira DA. Antibacterial activity of taninis from Psidium guineense Sw. (Myrtaceae). J Med Plant Res. 2014;8(35):15, doi: 10.5897/JMPR2014.5500

27. Panizzi L, Caponi C, Catalano S, Cioni PL, Morelli I. In vitro antimicrobial activity of extracts and isolated constituents of Rubus ulmifolius. J Ethnopharmacol. 2002;79(2):165-8, doi: 10.1016/s03788741(01)00363-4 
28. Oh J, Jo H, Cho AR, Kim SJ, Han J. Antioxidant and antimicrobial activities of various leafy herbal teas. Food Control. 2013;31(2):403-09, doi:10.1016/j.foodcont.2012.10.021

29. Aligianis N, Kalpoutzakis E, Mitaku S, Chinou IB. Composition and antimicrobial activity of the essential oil of two Origanum species. J Agric Food Chem. 2001;49(9):4168-70, doi: 10.1021/jf001494m

30. Gimenez DFJ, Dedemo GC, Vantini JS, Silva ACB, Tezza RID, Dabbas KM, Mutton MA, Ferro MIT. Análise dos parâmetros biométricos, acúmulo de prolina e identificação de genes envolvidos na resposta ao déficit hídrico em cana-de-açúcar por cDNA-AFLP. Científica. 2013;41(2):209-25, doi: 10.15361/1984-5529.2013v41n2p209-225

31. Aquino PEA, Magalhães TR, Nicolau LAD, Leal LKAM, Aquino NC, Santos SM, Neves KRT, Silveira ER, Viana GSB. The anti-inflammatory effects of N-methyl-(2S, 4R)-trans-4-hydroxy-1-prolina from Syderoxylon obtusifolium are related to its inhibition of TNT-alpha and inflammatory enzymes. Phytomed. 2017;24:14-23, doi: 10.1016/j.phymed.2016.11.010

32. Monteiro JM, Albuquerque UP, Lins-Neto EMF, Araújo EL, Amorim ELC. Use patterns and knowledge of medicinal species among two rural communities in Brazil's semi-arid northeastern region. J Ethnopharm. 2006;105(1-2):173-86, doi: 10.1016/j.jep.2005.10.016

33. Akiyama H, Fujii K, Yamasaki O, Takashi O, Iwatsuki K. Antibacterial action of several tannins against Staphylococcus aureus. J Antimicrob Chemother. 2001;48(4): 487-91, doi: 10.1093/jac/48.4.487

34. Djipa CD, Delmée M, Quetin-Leclercq J. Antimicrobial activity of bark extracts of Syzygium jambos (L) Alston (Myrtaceae). J Ethnopharmacol. 2000;71(1-2):307-13, doi: 10.1016/S0378-8741(99)00186-5 